\title{
Dinamika Populasi Kepiting Bakau (Scylla sp.) di Perairan Kabupaten Sinjai
}

\author{
RIDHA ALAMSYAH $^{1}$, A. LISWAHYUNI ${ }^{1}$, MAPPARIMENG $^{1}$, ARMITA PERMATASARI $^{1}$ \\ ${ }^{1}$ Manajemen Sumber Daya Perairan, STIP Muhammadiyah Sinjai \\ Jl. Teuku Umar No. 8 Biringere Kabupaten Sinjai, Sulawesi Selatan. 92611 \\ Email: alamsyahridha@gmail.com
}

Received 21 November 2017; Received in revised form 23 January 2018;

Accepted 2 February 2018; Available online 3 February 2018

\begin{abstract}
Mangrove crab catching activity to increase and tends to lead exploitation pressure. This study aims to determine the rate of growth, mortality, and rate of exploitation. Sampling on fishermen and collectors whose fishing locations are in predetermined areas. Measurements taken are using ruler and caliper 0,05 for carapace width. Sample measurements were carried out to obtain information on the dynamics of the mangrove crab population. The results obtained are: length of carapace minimum $\left(\mathrm{L}_{\min }\right) 61 \mathrm{~mm}$, maximum $\left(\mathrm{L}_{\max }\right) 173 \mathrm{~mm}$, Asimtot carapace width $(\mathrm{L} \infty)$ 177,7 $\mathrm{mm}$ with growth coefficient $(\mathrm{K})$ 0,1 per year, and the value $t_{0}$ obtained $-0,2907$. Total mortality rate $(Z) 0,743$ per year, natural mortality $(\mathrm{M}) 0,177$ per year and mortality of capture $(\mathrm{F})$ 0,566 per year. The rate of exploitation (E) 0,762 per year, indicating that there has been over exploitation of mangrove crabs in Sinjai District.
\end{abstract}

Keywords: exploitation rate, growth, mangrove crab, mortality, Sinjai

\section{INTISARI}

Aktivitas penangkapan kepiting bakau terus mengalami peningkatan dan cenderung mengarah ke tekanan eksploitasi. Penelitian ini bertujuan untuk mengetahui laju pertumbuhan, mortalitas, dan laju eksploitasi. Pengambilan sampel pada nelayan dan pengumpul yang lokasi penangkapannya pada daerah yang telah ditentukan sebelumnya. Pengukuran yang dilakukan adalah lebar karapaks dengan menggunakan mistar dan caliper $0,05 \mathrm{~mm}$. Pengukuran sampel dilakukan untuk mendapatkan informasi tentang dinamika populasi kepiting bakau. Hasil yang diperoleh antara lain lebar karapaks minimum $\left(\mathrm{L}_{\min }\right)$ adalah $61 \mathrm{~mm}$, maksimum $\left(\mathrm{L}_{\max }\right) 173 \mathrm{~mm}$, lebar karapaks asimtot $\left(\mathrm{L}_{\infty}\right)$ sebesar 177,7 mm dengan koefisien pertumbuhan $(\mathrm{K})$ sebesar 0,1 pertahun. Serta nilai $\mathrm{t}_{0}$ secara empiris didapatkan sebesar -0,2907. Laju mortalitas total (Z) sebesar 0,743 pertahun, mortalitas alami (M) sebesar 0,177 pertahun dan mortalitas penangkapan (F) 0,566 pertahun. Laju eksploitasi (E) sebesar 0,762 pertahun menunjukkan bahwa telah terjadi over eksploitasi terhadap kepiting bakau di Kabupaten Sinjai.

Kata kunci: kepiting bakau, laju eksploitasi, mortalitas, pertumbuhan, Sinjai

\section{PENDAHULUAN}

Kepiting bakau (Scylla sp.) merupakan salah satu komoditas perairan payau yang banyak diminati. Kandungan protein yang tinggi menyebabkan kepiting bakau banyak dicari dan disukai banyak orang (Catacutan, 2002). Permintaan terus meningkat khususnya pada kepiting yang sedang matang gonad untuk kebutuhan dalam negeri dan untuk keperluan ekspor (Dinas Kelautan dan Perikanan Kabupaten Sinjai, 2015). Kegiatan budidaya yang telah dilakukan belum mampu memenuhi kebutuhan dan permintaan pasar sehingga masih mengandalkan dari penangkapan di alam.

Populasi kepiting di alam telah mengalami penurunan yang diduga disebabkan oleh degradasi ekosistem mangrove dan tangkap lebih. Penggunaan alat tangkap yang tidak ramah lingkungan serta alih fungsi lahan mangrove menjadi tambak semakin memperparah kondisi sumber daya kepiting 
bakau secara alami. Laju eksploitasi yang terus meningkat berdampak terhadap penurunan populasi kepiting bakau di alam dan semakin mengecilnya ukuran kepiting yang tertangkap (Karim, 2013; Siahainenia, 2008; Bonine et. al., 2008).

Peningkatan eksploitasi, konversi habitat dan perubahan lingkungan menjadi faktorfaktor penyebab utama penurunan populasi kepiting bakau (Mohapatra et al., 2010; Lebata et al., 2009). Rachmawati (2009) menyatakan jika hal ini terus berlanjut dikhawatirkan akan terjadi overfishing atau over eksploitasi sehingga akan berdampak pada penurunan keanekaragaman kepiting bakau. Nilai keanekaragaman jenis dipengaruhi oleh jumlah individu suatu jenis dalam populasi (Cahyanto dkk., 2016). Ditambahkan oleh Triyanto $d k k$. (2013), penurunan populasi disebabkan hilangnya habitat alami (kerusakan ekosistem mangrove) juga disebabkan penangkapan (eksploitasi) secara berlebihan oleh nelayan sehingga menghilangkan kesempatan bagi kepiting bakau untuk berkembang dan tumbuh dengan baik.

Pada beberapa daerah di Indonesia kegiatan penangkapan kepiting bakau terus dilakukan. Seperti yang dikemukakan oleh Wijaya dkk. (2010) bahwa sumber daya kepiting bakau pada habitat mangrove Taman Nasional Kutai Kabupaten Kutai Timur telah berada diatas laju eksploitasi. Namun demikian berbeda dengan hasil penelitian Ningsih dkk. (2014) bahwa tingkat pemanfaatan kepiting bakau di pesisir Desa Tembeling Kepulauan Riau masih rendah ditandai dengan laju mortalitas alami yang lebih tinggi di banding mortalitas akibat penangkapan.

Kabupaten Sinjai adalah salah satu daerah dengan tingkat pemanfaatan kepiting bakau yang terus mengalami peningkatan. Berdasarkan data statistik perikanan Pada tahun 2012 sebanyak 48,12 ton meningkat menjadi 65,12 ton pada 2013 dan 66,15 ton pada tahun 2014 (Dinas Kelautan dan Perikanan Kab. Sinjai, 2015). Berkaitan dengan kondisi dan tingkat pemanfaatan kepiting bakau yang berbeda di beberapa daerah, dan kecenderungan peningkatan eksploitasi di Kabupaten Sinjai maka perlu upaya untuk mengetahui populasi kepiting bakau. Informasi tentang dinamika populasi akan menjadi dasar dalam pengelolaan sumber daya kepiting bakau.

\section{METODE}

Penelitian dilakukan pada bulan September sampai dengan November 2017. Teknik pengambilan data menggunakan metode survei dengan teknik cluster sampling. Beberapa cluster dipilih terlebih dulu sebagai tempat pengambilan sampel (Nazir, 2009). Pengambilan sampel kepiting bakau dari nelayan dan pengumpul yang lokasi penangkapannya pada daerah yang telah ditentukan sebelumnya. Pengukuran yang dilakukan yaitu lebar karapaks dengan menggunakan mistar dan caliper 0,05 mm.

Pengukuran sampel dilakukan untuk mendapatkan informasi tentang dinamika populasi kepiting bakau. Aspek dinamika populasi yang dikaji terdiri dari pertumbuhan, mortalitas, dan laju eksploitasi.

Pertumbuhan. Model pertumbuhan yang digunakan adalah model Von Bertalanffy dengan persamaan sebagai berikut:

$$
L_{t}=L \infty\left[1-e^{-K\left(t-t_{0}\right)}\right]
$$

Penentuan lebar karapaks asimtot kepiting $(L \infty)$ dan koefisien laju pertumbuhan $(K)$ menggunakan metode Ford dan Walford, yaitu dengan memplotkan $\mathrm{L}(\mathrm{t}+\Delta \mathrm{t})$ dan $\mathrm{L}(\mathrm{t})$ dengan persamaan: $\mathrm{L}(\mathrm{t}+\Delta \mathrm{t})=\mathrm{a}+\mathrm{b} \mathrm{L}(\mathrm{t})$, setelah mendapatkan persamaan regresi dari kedua hubungan. Nilai $L \infty$ dan $K$ didapatkan dari hasil perhitungan dengan metode ELEFAN I (Electronic Length Frequency's Analysis) yang terdapat dalam program FISAT II. Pendugaan umur teoritis pada saat lebar karapaks sama dengan nol $\left(\mathrm{t}_{0}\right)$ menggunakan rumus empiris Pauly sebagai berikut:

$$
\begin{aligned}
& \log \left(-t_{0}\right)=-0.3922-0,2752 \log L \infty-1,308 \log K \\
& \text { Keterangan: } \\
& L \infty \quad=\text { lebar karapaks asimtot kepiting (mm) } \\
& \mathrm{K}=\text { koefisien pertumbuhan (pertahun) } \\
& \mathrm{t}_{0}=\text { umur teoritis kepiting pada saat panjangnya sama } \\
& \text { dengan nol (tahun). }
\end{aligned}
$$

Mortalitas (Tingkat Kematian). Pendugaan mortalitas kepiting bakau 
dilakukan dengan penentuan parameterparameter pertumbuhan yang telah dihitung sebelumnya. Setelah nilai ini diketahui, maka dilakukan pendugaan laju mortalitas (Z) berdasarkan persamaan Beverton dan Holt:

$$
Z=K * \frac{(L \infty-\bar{L})}{\left(\bar{L}-L^{\prime}\right)}
$$

Pendugaan laju mortalitas alami menggunakan rumus empiris Pauly:

$$
\begin{gathered}
\log M= \\
-0,152-0,279 * \ln L \infty+0,6543 * \log K+0,463 * \log T
\end{gathered}
$$

Keterangan:

$\mathrm{T}=$ suhu perairan,

$\mathrm{Z} \& \mathrm{M}=$ menduga laju kematian kepiting akibat penangkapan $(\mathrm{F})$

$$
F=Z-M
$$

Laju Eksploitasi. Berdasarkan data mortalitas maka laju eksploitasi kepiting (E) dapat diduga dengan menggunakan persamaan sebagai berikut:

$$
E=\frac{F}{Z}
$$

Keterangan:

$\mathrm{Z} \quad=$ total laju mortalitas (pertahun)

$\mathrm{F} \quad=$ laju mortalitas penangkapan (pertahun)

$\mathrm{E} \quad=$ laju eksploitasi (pertahun)

\section{HASIL}

Pertumbuhan. Berdasarkan hasil pengukuran dan hasil perhitungan dengan menggunakan metode Ford dan Walford serta ELEFAN I maka didapatkan hasil sebagai berikut:

Tabel 1. Parameter pertumbuhan kepiting bakau (Scylla sp.) di Perairan Kabupaten Sinjai

\begin{tabular}{ccccccc}
\hline Parameter & $\mathbf{n}$ & $\mathbf{L}_{\min }(\mathbf{m m})$ & $\mathbf{L}_{\max }(\mathbf{m m})$ & $\mathbf{L}_{\infty}(\mathbf{m m})$ & $\mathbf{K}($ pertahun $)$ & $\mathbf{t}_{\mathbf{0}}$ \\
\hline Nilai & 580 & 61 & 173 & 177,7 & 0,1 & $-0,2907$ \\
\hline
\end{tabular}

Jumlah sampel yang diperoleh sebanyak 580 ekor. Lebar karapaks minimum $\left(\mathrm{L}_{\min }\right)$ adalah $61 \mathrm{~mm}$ dan maksimum $\left(\mathrm{L}_{\max }\right) 173 \mathrm{~mm}$. Lebar karapaks asimtot $\left(\mathrm{L}_{\infty}\right)$ sebesar $177,7 \mathrm{~mm}$ dengan koefisien pertumbuhan $(\mathrm{K})$ sebesar 0,1 pertahun. Nilai $t_{0}$ secara empiris didapatkan sebesar $-0,2907$. Nilai parameter pertumbuhan digunakan sebagai dasar dalam pembentukan kurva pertumbuhan Von Bertalanffy. Persamaan pertumbuhan kepiting bakau berdasarkan kurva pertumbuhan adalah $\mathrm{Lt}=$ $177,7\left[1-\mathrm{e}^{-0,1(\mathrm{t}-0,2907)}\right]$.

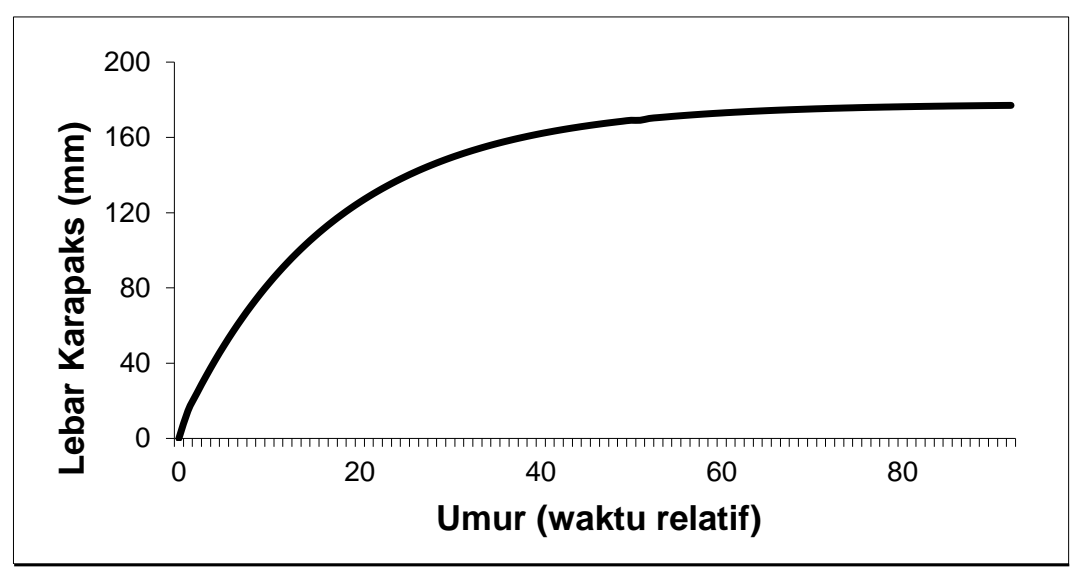

Gambar 1. Kurva pertumbuhan kepiting bakau (Scylla) yang tertangkap di Perairan Kabupaten Sinjai

Mortalitas. Mortalitas atau tingkat kematian kepiting bakau dianalisa dengan menggunakan persamaan Beverton dan Hold dan diperoleh hasil sebagai berikut:

Tabel 2. Laju mortalitas dan laju eksploitasi kepiting bakau (Scylla sp.) di Kabupaten Sinjai

\begin{tabular}{cccccc}
\hline Parameter & $\mathbf{n}$ & $\mathbf{Z}$ & $\mathbf{M}$ & $\mathbf{F}$ & $\mathbf{E}$ \\
\hline Nilai & 580 & 0,743 & 0,177 & 0,566 & 0,762 \\
\hline
\end{tabular}


Laju mortalitas total (Z) sebesar 0,743 pertahun, sedangkan laju mortalitas alami (M) sebesar 0,177 pertahun dan mortalitas penangkapan (F) sebesar 0,566 pertahun.

Laju Eksploitasi. Hasil perbandingan antara mortalitas penangkapan terhadap mortalitas total adalah merupakan nilai dari laju eksploitasi. Nilai laju eksploitasi (E) yang diperoleh adalah sebesar 0,762 pertahun,

\section{PEMBAHASAN}

Pertumbuhan kepiting bakau merupakan pertambahan berat dan lebar karapaks yang terjadi secara berkala. Pertumbuhan ditandai dengan pergantian kulit atau molting. Nilai koefisien pertumbuhan $(\mathrm{K})$ yang didapatkan mengindikasikan bahwa laju pertumbuhan kepiting bakau di Kab. Sinjai cenderung lambat. Kecepatan pertumbuhan berbeda antara satu daerah dengan daerah lainnya. Wijaya (2011) di perairan Kutai mendapatkan nilai koefisien pertumbuhan kepiting bakau 0,45-5,2 pertahun dengan $\mathrm{L}_{\infty} 161,18 \mathrm{~mm}$. Sedangkan Kumalah $d k k$. (2017) di perairan Subang berkisar $0,11-0,50$ pertahun dengan $\mathrm{L}_{\infty}$ 170,85 .

Pertumbuhan kepiting bakau sama dengan pertumbuhan organisme pada umumnya, cepat pada fase muda dan melambat seiring dengan bertambahnya umur sampai pada lebar karapaks asimtot ( $\left.\mathrm{L}_{\infty}\right)$. Menurut Karim (2013), selama masa pertumbuhan kepiting bakau akan mengalami molting berkisar antara 17 sampai 20 kali, dengan pertambahan 20-30\% dari ukuran semula. Kualitas lingkungan sangat mempengaruhi pertumbuhan kepiting bakau, hal ini sesuai dengan pernyataan Siahainenia (2008) bahwa fluktuasi salinitas dan tinggi rendahnya ketersediaan makanan alami mempengaruhi kecepatan pertumbuhan.

Laju pertumbuhan kepiting bakau dalam satu daerah merupakan informasi dasar dalam upaya pengelolaan sumber daya. Parameter tersebut dapat memberikan kontribusi terhadap pendugaan produksi dan laju kematian suatu populasi.

Mortalitas adalah angka kematian suatu populasi. Laju mortalitas disebabkan oleh tingkat kematian alami karena usia, perubahan lingkungan atau rendahnya daya dukung lingkungan dan aktivitas penangkapan (Alongi, 2002; Jackson et al., 2001). Tingkat kematian akibat penangkapan (F) kepiting bakau di Kab. Sinjai jauh lebih tinggi dibandingkan dengan tingkat kematian alami. Hal ini menandakan bahwa keberadaan kepiting bakau mengarah pada tekanan eksploitasi.

Laju mortalitas penangkapan di perairan Kutai lebih tinggi ( $\mathrm{F}=0,718-1,927$ pertahun) dibandingkan dengan mortalitas alami ( $M=0,642-1,258$ pertahun) (Wijaya, 2011). Berbeda dengan hasil Kumalah $d k k$. (2017) di perairan Subang, $F=0,270-0,490$ pertahun sedangkan $\mathrm{M}=0,250-0,790$ pertahun. Laju mortalitas alami cenderung lebih tinggi dibandingkan dengan laju mortalitas penangkapan.

Laju eksploitasi kepiting bakau adalah akibat dari aktivitas penangkapan. Penangkapan dikatakan optimal apabila laju eksploitasi $(E)=0,5$, jika $E>0,5$ menunjukkan telah terjadi over eksploitasi, sedangkan jika $\mathrm{E}<0,5$ menunjukkan tingkat eksploitasi rendah (Gulland, 1971 dalam Kumalah dkk., 2017). Hasil perhitungan laju eksploitasi kepiting bakau di Kab. Sinjai sebesar 0,762 > 0,5 atau dengan kata lain tingkat eksploitasi tinggi (over eksploitasi).

Hasil penelitian Wijaya (2011), menyatakan bahwa laju eksploitasi kepiting bakau di perairan Kutai berkisar antara 0,4070,606 . Sedangkan menurut Kumalah $d k k$. (2017) di perairan Subang berkisar antara 0,330-0,550. Laju eksploitasi yang tinggi di beberapa daerah disebabkan karena tingkat penangkapan yang cukup tinggi dan rendahnya produksi dari hasil budidaya. Tingginya permintaan terutama pada kepiting bakau betina yang matang gonad.

\section{KESIMPULAN}

Parameter Pertumbuhan Von Bartalanffy kepiting bakau di perairan Sinjai adalah $\mathrm{L}_{\infty}$ $177,7 \mathrm{~mm}$ dan $\mathrm{K} 0,1$ pertahun, persamaan kurva pertumbuhan $\mathrm{Lt}=177,7\left[1-\mathrm{e}^{-0,1(\mathrm{t}-0,2907)}\right]$. Laju mortalitas total (Z) sebesar 0,743 pertahun, mortalitas alami (M) sebesar 0,177 pertahun dan mortalitas penangkapan (F) sebesar 0,566 pertahun. Nilai laju eksploitasi 
(E) sebesar 0,762 pertahun, menunjukkan bahwa telah terjadi over eksploitasi.

\section{UCAPAN TERIMA KASIH}

Terima kasih kepada Ketua STIP Muhammadiyah Sinjai dan Ketua Lembaga Penelitian dan Pengabdian Kepada Masyarakat atas dukungan materi sehingga penelitian ini diselesaikan sesuai dengan rencana.

\section{DAFTAR PUSTAKA}

Alongi DM. 2002. Present State and Future of The World's Mangrove Forests. Environmental Conservation. vol 29(3): 331-349.

DOI: https://doi.org/10.1017/S0376892902000 231.

Bonine KM, Bjorkstedt EP, Ewel KC, Palik M. 2008. Population Characteristics of the Mangrove Crab Scylla serrata (Decapoda: Portunidae) in Kosrae, Federated States of Micronesia: Effects of Harvest and Implications for Management. Pacific Science. vol 62(1): 1-19. DOI: https://doi.org/10.2984/15346188(2008)62[1:PCOTMC]2.0.CO;2.

Cahyanto T, Arigustin D, Efendi M. 2016. Keanekaragaman Jenis Bambu di Gunung Ciremai Jawa Barat. Biogenesis. vol 4(2): 90-94.

DOI: http://dx.doi.org/10.24252/bio.v4i2.2513.

Catacutan MR. 2002. Growth and body composition of juvenile mud crab, Scylla serrata, fed different dietary protein and lipid levels and protein to energy ratios. Aquaculture. vol 208(1-2): 113-123. DOI: http://dx.doi.org/10.1016/S00448486(01)00709-8.

Dinas Kelautan dan Perikanan Kabupaten Sinjai. 2015. Statistik Perikanan Kabupaten Sinjai Tahun. 2014. DKP Sinjai. hal 47.

Jackson JB, Kirby MX, Berger WH, Bjorndal KA, Botsford LW, Bourque BJ, Bradbury $\mathrm{RH}$, Cooke R, Erlandson J, Estes JA, Hughes TP. 2001. Historical Overfishing and the Recent Collapse of Coastal Ecosystems. Science. vol 293(5530): 629637.

DOI:
Karim MY. 2013. Kepiting Bakau (Scylla spp.) (Bioekologi, Budidaya, dan Pembenihannya). Jakarta: Yarsif Watampone. hal 3-21.

Kumalah AA, Wardiatno Y, Setyobudiandi I, Fahruddin A. 2017. Biologi Populasi Kepiting Bakau Scylla serrata Forsskal, 1775 di Ekosistem Mangrove Kabupaten Subang, Jawa Barat. Jurnal Ilmu dan Teknologi Kelautan Tropis. vol 9(1): 171184.

DOI: http://dx.doi.org/10.29244/jitkt.v9i1.1792 8.

Lebata MJHL, Le vay L, Walton ME, Biñas JB, Quinitio ET, Rodriguez EM, Primavera JH. 2009. Evaluation of Hatchery-Based Enhancement of the Mud Crab, Scylla spp., Fisheries in Mangroves: Comparison of Species and Release Strategies.Marine and Freshwater Research. Vol 60(1): 58-69. DOI: http://dx.doi.org/10.1071/MF08155.

Mohapatra A, Mohanty RK, Mohanty SK, Dey SK. 2010. Carapace width and weight relationship, Condition Factor, Relative Condition Factor and Gonado-Somatic Index (GSI) of Mud Crabs (Scylla spp.) from Chilika Lagoon, India. Indian Journal of Marine Sciences. vol 39(1): 120-127.

Nazir M. 2009. Metode Penelitian. Jakarta: Ghallia Indonesia. hal 277.

Ningsih SR, Lestari F, dan Zulfikar A. 2014. Kajian Stok Kepiting Bakau (Sylla sp.) di Ekosistem Pesisir Kampung Gisi Desa Tembeling Kabupaten Bintan Provinsi Riau. [Skripsi]. Tanjung Pinang: Fakultas Ilmu Kelautan dan Perikanan, Universitas Maritim Raja Ali Haji.

Rachmawati PF. 2009. Analisa Variasi Karakter Morfometrik dan Meristik Kepiting Bakau (Scylla spp.) di Perairan Indonesia. [Skripsi]. Bogor: Institut Pertanian Bogor.

Siahainenia L. 2008. Bioekologi Kepiting Bakau (Scylla spp.) di Ekosistem Mangrove Kabupaten Subang Jawa Barat. [Disertasi]. Bogor: Institut Pertanian Bogor. 
Triyanto NI, Wijaya T, Yuniarti, Widianti, F, Sutrisno F, Setiawan, dan Lestari S. 2013. Peranan ekologis hutan mangrove dalam Menunjang produksi kepiting perikanan bakau (Scylla serrata) di Kabupaten Berau. Prosiding Pertemuan Ilmiah Tahunan MLI I-2013. hal 275-284.

Wijaya NI, Yulianda F, Boer M, dan Juana S. 2010. Biologi Populasi Kepiting Bakau (Scylla serata F.) di Habitat Mangrove
Taman Nasional Kutai Kalimantan Timur. Jurnal Oseanologi dan Limnologi Indonesia. vol 36(3): 443-461.

Wijaya NI. 2011. Pengelolaan Zona Pemanfaatan Ekosistem Mangrove Melalui Optimasi Pemanfaatan Sumber daya Kepiting Bakau (Scylla serrata) di Taman Nasional Kutai Provinsi Kalimantan Timur. [Disertasi]. Bogor: Institut Pertanian Bogor. 